\title{
DYNAMIC RESPONSE OF A MATERIAL DURING A HIGH-SPEED IMPACT
}

\author{
DINAMIČNI ODGOVOR MATERIALA NA ZELO HITRE TRKE \\ (UDARCE)
}

\author{
Jan Raška, Martin Oberthor* \\ Czech Aerospace Research Centre (VZLÚ), Beranových 130, 19905 Praha - Letňany, Czech Republic \\ Prejem rokopisa - received: 2019-07-15; sprejem za objavo - accepted for publication: 2019-11-04
}

doi:10.17222/mit.2019.158

\begin{abstract}
The material of an aircraft structure must resist a high-speed impact - an impact of a bird or hail at the flight speed (a bird strike or hail strike). The proof of this resistance can be provided in the experimental or numerical way. The recent development of numerical methods takes advantage of the numerical way. However, the necessity to verify the used numerical models creates new challenges for the experiments. The goal is to measure and record a great deal of data during the very short time of a high-speed impact. The use of high-speed load cells makes it possible to record the time-dependent force response of an impact event. However, the major difficulty of this approach is the existence of parasitic resonances. The experimental stand, the support of the studied specimen, exhibits an eigen dynamic response and in consequence, the final measured dynamic response is coupled with the stand-structure one. The objective of a stand design is therefore to minimize these parasitic resonances, occurring due to the stand-structure dynamics. In this way, special equipment for the experimental research of the dynamic response during a high-speed impact is designed and realized. The stand is to support the specimen during the impact of a projectile (a bird or hail) ejected from a pneumatic gun. The stand design enables an impact at any angle (from $0^{\circ}$ to $90^{\circ}$ ), without changing the contact point. The dynamic-response measurement is realized by means of load cells. The equipment is designed and optimized by means of FEM numerical simulations with the aim to minimize the parasitic resonances of the stand structure.

Keywords: high-speed impact, bird strike, hail strike, impact projectile, parasitic resonances, virtual-load-cell record

Strukture iz materialov za letala morajo prenesti trke različnih predmetov, ki z veliko hitrostjo udarjajo vanje. To so lahko udarci ptic, toče ali drugih delcev med potovanjem letala z veliko hitrostjo. Odpornost proti takšnim udarcem lahko določimo eksperimentalno ali numerično oz. z računalniškimi simulacijami, ki imajo z razvojem novih metod mnoge prednosti. Vendar pa je numerične metode oz. modele potrebno eksperimentalno verificirati, kar predstavlja določen izziv. Cilj je merjenje in zapisovanje velikega števila podatkov v zelo kratkem času, zelo hitrega udarca. Uporaba celic za merjenje hitrih obremenitev omogoča zapisovanje odgovora časovno odvisnih sil med trki. Vendar je pri tem glavna težava tega pristopa nastanek škodljivih (parazitnih) resonanc. Izdelano eksperimentalno stojalo je bilo podpora za študiranje primerov z lastnimi vrednostmi dinamičnega odgovora in posledično končnimi izmerjenimi dinamičnimi odgovori v povezavi s strukturo stojala. Cilj oblikovanja stojala je zato zmanjšanje takšnih škodljivih resonanc zaradi dinamike strukture stojala. Na ta način so avtorj oblikovali in izdelali posebno opremo za eksperimentalne raziskave dinamičnega odgovora med udarjanjem zelo hitrih projektilov. Stojalo je prenašalo udarce različnih projektilov, ptic ali toče, izstreljenih s pnevmatskim topom. Oblika stojala je omogočala izvajanje udarcev pod kakršnimkoli kotom (od $0^{\circ}$ do $90^{\circ}$ ), ne da bi prišlo do spremembe udarne točke. Meritve dinamičnega odgovora so izvajali z merilnimi celicami za zelo hitre obremenitve. Opremo so oblikovali in optimizirali glede na potrebe numeričnih simulacij, izvedenimi z metodami končnih elementov (FEM) in s ciljem minimiziranja škodljivih resonanc
\end{abstract} strukture eksperimentalnega stojala.

Ključne besede: udarci z veliko hitrostjo, udarci ptic, toče in projektilov, škodljive resonance, beleženje dejanskih obremenitev s senzorji (celicami) za zelo hitre obremenitve

\section{INTRODUCTION}

Airworthiness standards require the resistance of aircraft structures to a high-speed impact - an impact of a bird or hail at the flight speed (a bird strike or hail strike) ${ }^{1,2}$ The proof of this resistance can be provided in the experimental or numerical way. The recent development of numerical methods, especially the explicit solution of the finite-element method, takes advantage of the numerical way. ${ }^{5}$ However, the necessity to verify the used numerical models - particularly the model of a material damage and the constitutive model of an impact body (projectile) - creates new challenges for the experiments. The goal is to measure and record a great deal of

*Corresponding author's e-mail:

raska@vzlu.cz (Jan Raška) data during a very short time of a high-speed impact. This is technically demanding, but necessary for a numerical-model verification. ${ }^{4}$

The use of high-speed load cells makes it possible to record the time-dependent force response of an impact event. However, the major difficulty of this approach is the existence of parasitic resonances. The experimental stand, the support of a studied specimen, exhibits an eigen dynamic response and in consequence, the final measured dynamic response is coupled with the stand-structure one. The objective of the stand design is therefore to minimize these parasitic resonances, occurring due to the stand-structure dynamics. For this reason, at the first iteration, the equipment was optimized by means of FEM numerical simulations. 


\section{SPECIMENS}

The experimental stand was designed for large flat panels, convenient for advanced developmental experiments. The disadvantage of a standard square (or rectangle) specimen is the risk of non-regular flaws (Figure 1). ${ }^{4}$

The specimen is typically over-loaded at the centers of the edges, causing the risk of cracks and disruptions, while damages of a specific form can appear in the corners. To avoid these types of flaws, we should use a round specimen as the optimum form is the circle. For the technological reasons, an octahedron was adopted (Figure 2).

\section{EXPERIMENTAL-STAND CONCEPTION}

Three basic objectives were set when designing the equipment. At first, the stand was designed to support a specimen during an impact of a projectile (a bird or hail) ejected from a pneumatic gun. Secondly, the equipment was adapted to the dynamic-response measurement and recording by means of load cells.

At last, the stand design enabled an impact at any angle (from $0^{\circ}$ to $90^{\circ}$ ), without changing the first contact point. This means that in all cases, the gun axis points to the center of the specimen. At any impact angle, the first contact of a bird or hail with a specimen occurs at its center.

For this reason, the stand structure is divided into two parts. The movable part is connected with the fixed one by means of pivots placed in the plane of the specimen

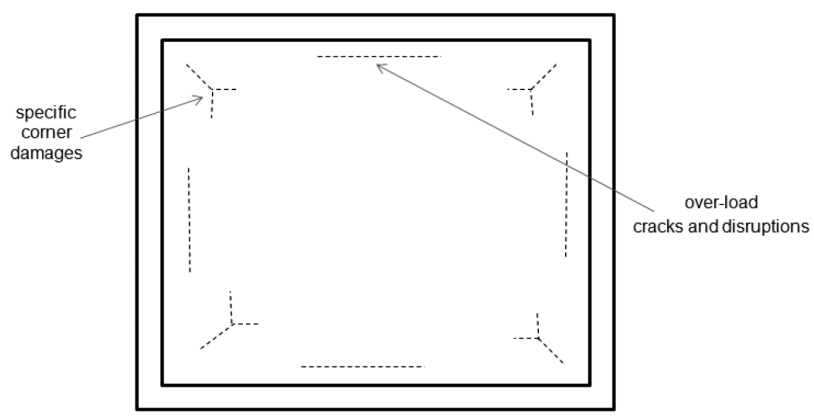

Figure 1: Typical non-regular flaws of a standard square specimen
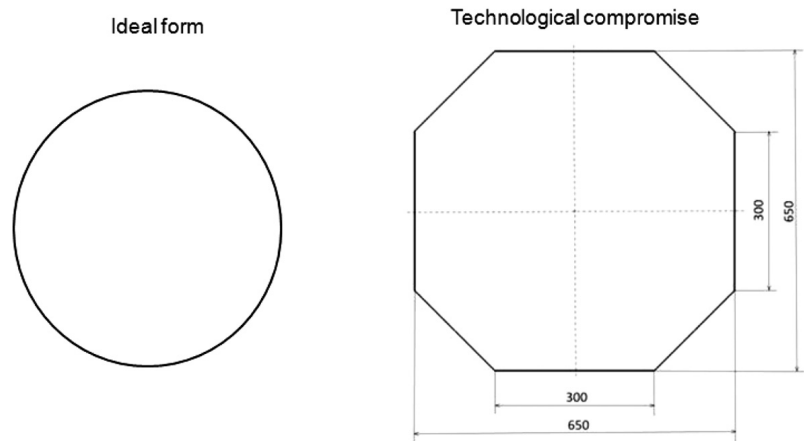

Figure 2: Optimized specimen form
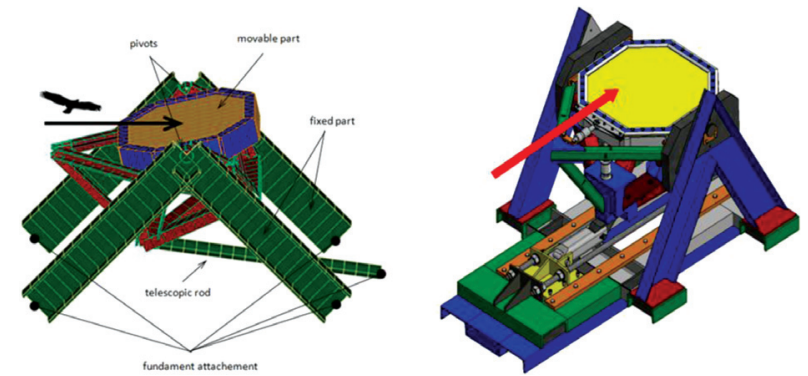

Figure 3: Experimental-stand configuration for a low-angle impact ${ }^{7,8}$

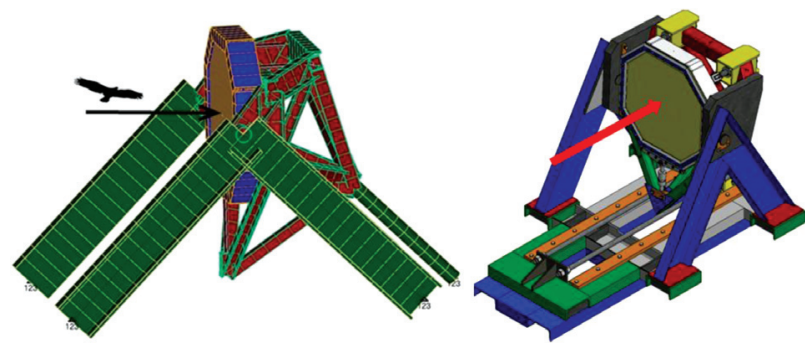

Figure 4: Experimental-stand configuration for a perpendicular impact $^{7,8}$

(Figures 3 and 4). In consequence, the gun axis always points to the same point, to the center of the specimen. ${ }^{8}$

The impact angle is controlled, in principle, with a telescopic rod. As demonstrated on Figure 3, if the telescopic rod is made long, the impact angle decreases. By contrast, a short telescopic rod allows a large impact angle. On Figure 4, a perpendicular impact is demonstrated. The real, detailed design is a little different (see the right parts of Figures 3 and 4). ${ }^{9}$

\section{NUMERICAL SIMULATIONS AND OPTIMISATION}

The major difficulty of a time-dependent force-response measurement during an impact event, by means of high-speed load cells, is the existence of parasitic resonances. ${ }^{7}$ The experimental stand exhibits an eigen dynamic response and in consequence, the final measured dynamic response is coupled with the stand-structure one. For this reason, the minimization of these parasitic resonances was the priority objective.

For the first iteration of the detailed design, FEM numerical simulations were applied. The finite-element model was loaded with the time-dependent force function, simulating the contact interaction between the projectile (bird or hail) and the specimen. The number of appropriate force functions was deduced in the analytical way (with some arbitrary assumptions), in the empirical way (experimental results) and with numerical simulations (an explicit FEM solution, a liquid-like bird model). ${ }^{1}$

The time-dependent force function, applied to the complete structure model (a specimen, the stand structure and the load-cell model) causes a dynamic response. 


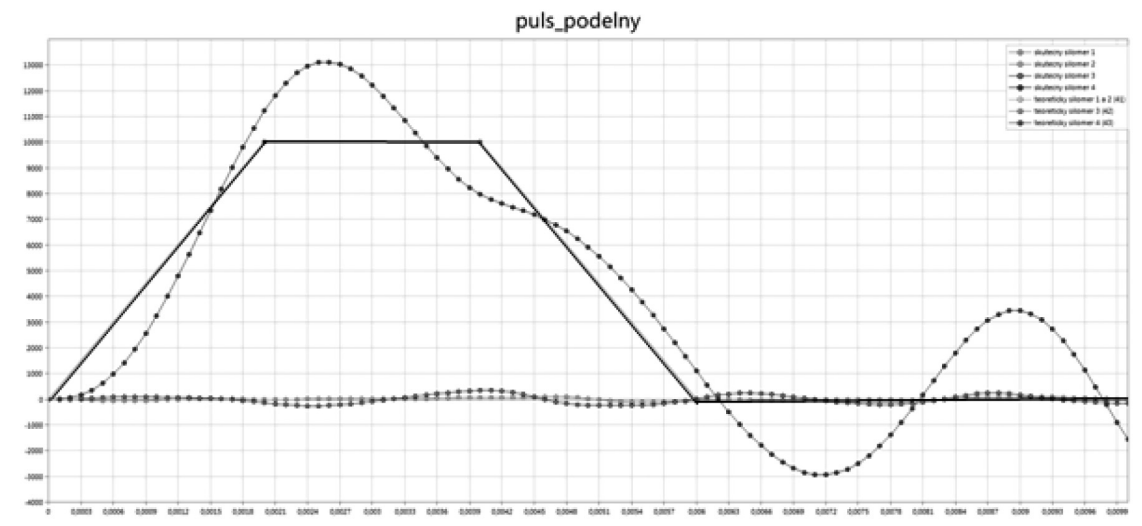

Figure 5: Example of virtual-load-cell records for a specimen-plane applied force ${ }^{7}$

The dynamic behavior is analyzed by means of a numerical FE simulation. The essential result is the timedependent virtual-load-cell record - the computed internal force of the FE elements - simulating the load cells. In an ideal case, the stand-structure parasitic resonances are completely negligible and in consequence, the virtual-load-cell record corresponds to the force applied via equilibrium conditions. In the real case, the deviations from the equilibrium condition are incurred due to the parasitic-resonance influence. The goal of the optimization is to minimize, as much as possible, the parasitic resonances for all the applied force functions. ${ }^{3}$

The example demonstrated on Figure 5 shows the case of the force applied to the specimen plane (the force due to the friction between the projectile and the specimen in the case of a small-angle impact). Theoretically, only one load cell is loaded. According to the equilibrium condition, the load of this load cell is equal to the applied force.

As it is observed on Figure 5, the applied force (the black solid line) is not exactly equal to the virtual-loadcell record. The applied force function has a trapezoid form; after a short impact pulse, the applied force is zero. The virtual-load-cell record oscillates around the applied force function. This deviations are relatively important; however, the oscillations at only one dominant frequency are easily eliminated with filtration. Virtual records of the other load cells are very close to the theoretical value, very close to zero.

\section{CONCLUSIONS}

Special experimental equipment for researching dynamic response during a high-speed impact was designed, developed and realized. The challenge was to measure and record a great deal of data during the very short time of a high-speed impact, necessary for a complex-numerical-model verification.

The stand was destined to support the specimen during an impact of a projectile (a bird or hail) ejected from a pneumatic gun. The specimen was defined as a large flat panel with a special octahedron form to avoid non-regular flaws. The stand design enabled an impact at any angle (from $0^{\circ}$ to $90^{\circ}$ ), without changing the contact point. Irrespective of the impact angle, the gun axis always points to the same point, to the center of the specimen.

The dynamic-response measurement was realized by means of load cells. For the first iteration of the detailed design, the equipment was designed and optimized by means of FEM numerical simulations with the aim to minimize the parasitic resonances of the stand structure.

\section{REFERENCES}

${ }^{1}$ R. Hedayati, M. Sadighi, Bird Strike, An Experimental, Theoretical and Numerical Investigation, 2016

${ }^{2}$ K. Hyonny, Impact Damage Formation on Composite Aircraft Structures, UCSD Federal Aviation Administration JAMS Paper, 2014

${ }^{3}$ R. Doubrava, M. Oberthor, P. Bělský, M. Dvořák, K. Doubrava, Experimental Verification of Jet Engine Composite Inlet for Bird and Hail Impact Resistance, Conference proceeding of 56th conference on experimental stress analysis (2018)

${ }^{4}$ R. Doubrava, M. Oberthor, P. Bělský, J. Raška, Bird and hail impact resistance analysis on jet engine composite air inlet, MATEC Web Conf., 188 (2018), doi:10.1051/matecconf/201818804006

${ }^{5}$ K. Kustron, V. Horak, R. Doubrava, Z. J. Goraj, New hail impact simulation models on composite laminated wing leading edge, Aircraft Engineering and Aerospace Technology, 91 (2018) 3, 457-465, doi:10.1108/AEAT-02-2018-0089

${ }^{6}$ R. Doubrava, M. Oberthor, K. Doubrava, M. Dvořák, Verification and numerical simulation of advanced composite inlet in compliance of airworthiness impact requirements, 13th Research and Education in Aircraft Design Conference 2018, doi:10.13164/conf.read.2018.1, https://dspace.vutbr.cz/bitstream/handle/11012/137289/READ-201801.pdf? sequence $=1$

${ }^{7}$ R. Doubrava, M. Oberthor, P. Bělský, O. Vích, An improvement of measurement technique for high speed impact tests analysis, EAN 2019 Conference Proceedings

${ }^{8}$ J. Raška: Numerical simulations and strenght check of the highspeed impact system, VZLÚ report R-6656, 2016

${ }^{9} \mathrm{M}$. Oberthor, Universal equipment for the research of the dynamic responce of a composit material during a high-speed impact, VZLÚ report R-6639, 2016 